

\title{
Kennis over kinderarbeid ter discussie $e^{(1)}$
}

\author{
Karl Hanson, wetenschappelijk medewerker, \\ Centrum voor de Rechten van het Kind, Universiteit Gent
}

\begin{abstract}
Beleidsinstrumenten en actieprogramma's over kinderarbeid beroepen zich al te vaak op relatief eenvoudige modellen en recepten om kinderarbeid te verklaren en aan te pakken. Nochtans komen in wetenschappelijk onderzoek en tijdens congressen over kinderarbeid steeds complexere analyses aan bod. Het groeiende inzicht in de vele dimensies van kinderarbeid en in de diversiteit van de vaak zeer subtiele vormen van uitbuiting van werkende kinderen, hoofdzakelijk in het Zuiden, heeft ook gevolgen voor de benadering van kinderarbeid in de geschiedenis. Nieuwe vormen van kennis over kinderarbeid vandaag beinvloeden de vragen die we aan onze kennis over kinderarbeid wit het verleden stellen. Dit themanummer bundelt een aantal bijdragen die een weergave bieden van sommige meer recente inzichten uit sociaalwetenschappelijk, juridisch en historisch onderzoek over kinderarbeid en werkende kinderen. Als inleiding bij deze discussies geven we een overzicht van een aantal kernthema's uit het debat. Daarbij besteden we aandacht aan discussies over de definitie van kinderarbeid, over kinderarbeid in ciffers, over de relatie arbeid en onderwijs, over zelforganisaties van werkende kinderen en over verschillende reacties om iets aan de situatie van werkende kinderen te doen. Eerst gaan we echter in op het mogelijke belang van deze discussies voor onze kijk op kinderarbeid in het verleden.
\end{abstract}

\section{Nieuwe vragen over kinderarbeid}

Allerlei bewustmakingscampagnes en televisiedocumentaires wezen de afgelopen jaren indringend op het bestaan van het fenomeen kinderarbeid. De informatie omvatte onder meer beelden van vijfjarigen die met zware bakstenen sjouwen, reportages over 
kinderen die voor een hongerloon in slecht verlichte textielateliers werken of interviews met actievoerders die jonge schuldslaven uit suikerrietplantages bevrijden. De algemene kennis over kinderarbeid is vooral beinvloed door campagnes die de meest schrijnende vormen van exploitatie van het werk van kinderen aan de kak stellen en willen afschaffen. Tegenover de harde realiteit van de kinderarbeid in het Zuiden wordt daarbij dikwijls een ideale kindertijd in de rijke landen geplaatst. Dit is echter een beeld dat niet echt klopt. Kinderen hebben niet de ganse dag de tijd om te huppelen en te springen, want ze moeten naar school. Sommige kinderen worden op school door medeleerlingen gepest of door leerkrachten geïntimideerd. Zelfmoord is een van de hoogste doodsoorzaken bij West-Europese schoolgaande tieners. De kindertijd is ook in rijke landen niet elke dag van de week een romantisch sprookje. Ook het verhaal over de uitbuiting en de miserie van werkende kinderen in het Zuiden omvat maar een deel van de werkelijkheid. Veel kinderen in arme landen leiden inderdaad een hard leven. Minder bekend is dat werkende kinderen in het Zuiden zich ook verenigen, en zelf standpunten innemen over hun situatie. In West-Afrika namen organisaties van werkende kinderen in 1994 voor het eerst deel aan de 1-meioptocht. De werkende kinderen vinden dat ook zij als werknemers aan de dag van de arbeid moeten participeren. Zelforganisaties van werkende kinderen pleiten onder meer voor de erkenning van hun recht op arbeid, voor de verbetering van hun arbeidsomstandigheden, voor betere gezondheidsvoorzieningen en voor het invoeren of uitbreiden van mogelijkheden om hun werk met onderwijs te combineren. De meesten van hen stellen dan ook vragen bij de dringende noodzaak, laat staan de mogelijkheid, om alle kinderarbeid onmiddellijk af te schaffen. Ook antropologisch onderzoek over kinderarbeid in het Zuiden geeft een heel genuanceerd beeld over de plaats en de betekenis van het werk van kinderen. Onderzoekers wijzen erop dat arbeid op vele plaatsen een heel normale plaats inneemt in het kinderleven van alledag. Niet alle kinderen in het Zuiden die werken doen dit in de meest ellendige omstandigheden. Toch is onze kennis over kinderarbeid hoofdzakelijk daartoe beperkt: kinderarbeid is een schrijnende vorm van exploitatie, een onrecht dat zo gauw mogelijk moet worden afgeschaft.

Discussies over kinderarbeid in het Zuiden verwijzen dikwijls naar de West-Europese geschiedenis, die als voorbeeld dient voor hoe kinderarbeid succesvol kan worden afgeschaft. Ook beschrijvingen van de levensomstandigheden van werkende kinderen vandaag trekken de parallel met de erbarmelijke levensomstandigheden van werkende kinderen tijdens de industrialisatie in het Westen. Werkende kinderen in de 19e.eeuw waren als machines onder de machines, die in benauwend slechte omstandigheden eindeloos lange dagen in hoog tempo moesten werken: "In de stoffige spinnerij liepen kleine jongens voortdurend langs de spinmolens op en neer om de gebroken draden te herstellen en in het naaiatelier zaten jonge meisjes knopen te naaien tot hun ogen er van pijn deden"(2). Ter illustratie van de erbarmelijke omstandigheden waarin kinderen vroeger moesten werken, verwijzen René De Herdt en Bie De Graeve naar de getuigenis van Pol De Witte (1848-1929), 
Gents arbeider en pionier van de arbeidersbeweging. Uit zijn autobiografie nemen ze de weinig rooskleurige beschrijving over van zijn eerste werkdag in een Gentse katoenspinnerij. Pol zou 'deurhaler' worden, en zijn vader troont hem mee om hem aan zijn aanstaande baas voor te stellen: "Voor't afscheid liet vader niet na zijne getwone aanbeveling ten beste te geven: 'als hij niet goed oplet, of zich niet voegt, legt er maar de lap op; ge zult er van mijgeen ondank van halen'”(3). Bart De Wilde plaatst een aantal kritische kanttekeningen bij de wijze waarop de geschiedenis van de 19e-eeuwse kinderarbeid in het Westen wordt voorgesteld ${ }^{(4)}$. De auteur stelt dat uit een breed aanbod van bronnen een eenzijdige selectie wordt gemaakt. Studies verwijzen bijna uitsluitend naar materiaal dat vooral de ellende en exploitatie van werkende kinderen illustreert. Over de passage uit de getuigenis van Pol De Witte merkt De Wilde op dat enkel het slechts zeer kortstondige verblijf (1 dag) in de spinnerij aan bod komt. Wat niet wordt verteld, is dat De Witte een aantal bladzijden verder een andere gelijkaardige ervaring als bijzonder positief evalueert. Over zijn start als kleermakersgast op de dag na zijn enige werkdag in de spinnerij - hij was toen 11 jaar - was De Witte alvast heel wat enthousiaster: "Het zal zeker niemand bevreemden dat dit leventje mij veel beter beviel dan dat op de fabriek. Ja, het viel zo goed in mijn smaak dat ik met medelijden op de vroegere schoolmakkerijes die nog naar school moesten begon neer te zien"(5). Volgens De Wilde blijkt uit bovenstaande getuigenis, naast andere bronnen, dat arbeid voor kinderen niet automatisch gelijk stond aan misbruik, maar veel meer was dan dat. Het kon ook een middel zijn om kinderen verantwoordelijkheidszin bij te brengen. Hun werk bezorgde hen zelfs een zekere eigenwaarde: ook voor kinderen kon arbeid emanciperend werken.

Zoals elke vorm van wetenschapsbeoefening vertrekt ook de geschiedenis 'van ergens'. Wie kinderarbeid beschouwt als een gesel die zo snel mogelijk moet worden uitgeroeid, loopt veel kans om in historische bronnen vooral die elementen terug te vinden die wijzen op de mensonterende arbeidsomstandigheden van werkende kinderen. Het eenzijdig benadrukken van kinderarbeid als moreel onrecht houdt het risico in dat werkende kinderen tijdens de industrialisering in de 19e eeuw enkel nog als onmondige slachtoffers worden gezien, en niet ook als producenten van waarde of als zingevers die over hun eigen situatie een mening hadden. De geschiedenis van kinderarbeid kan echter ook 'van ergens anders' worden geschreven. De wijzigende inzichten in kinderarbeid vandaag kunnen dienen voor het afbakenen van andere standpunten van waaruit naar de geschiedenis wordt gekeken. Twee invalshoeken uit het actuele wetenschappelijk debat over kinderarbeid zijn in het bijzonder relevant voor het bepalen van dit andere vertrekpunt over kinderarbeid. Een eerste thema handelt over de complexiteit van het onderwerp en benadrukt de noodzaak om kinderarbeid ook steeds vanuit zijn verschillende contexten te analyseren. Veel actueel onderzoek naar kinderarbeid stelt dat met de enorme diversiteit aan lokale realiteiten waar kinderen werken moet worden rekening gehouden, en dat ook deze diversiteit zelf moet worden gethematiseerd. Een tweede thema betrekt ook werkende kinderen zelf als actoren bij de discussies. 


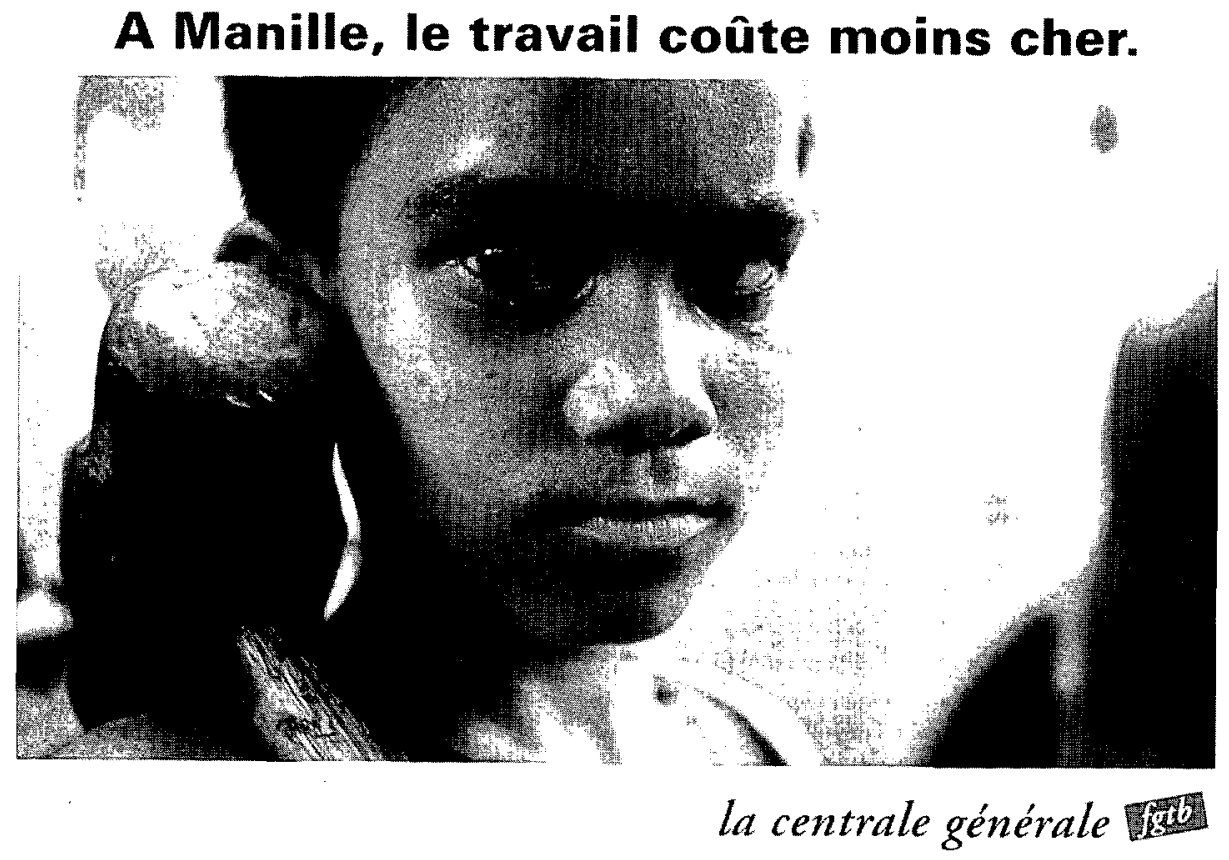

Affiche van de Algemene Centrale waarop kinderuitbuiting wordt gehekeld, 1980 
De eigen beleving van werkende kinderen en hun percepties en standpunten in het debat komen aan bod. Hoe begrijpen werkende kinderen zelf de omstandigheden waarin zij moeten werken? Wat zijn hun inzichten in of eisen voor hun concrete arbeidssituatie? Kinderarbeid wordt hier niet op de eerste plaats gezien als een verhaal over onschuldige kinderen als passieve slachtoffers. Werkende kinderen zelf treden op de voorgrond; ze worden als goed ingelichte en mondige actoren bij de discussie betrokken.

Beide invalshoeken stellen de bestaande kennis over kinderarbeid vandaag in vraag. Op theoretisch vlak worden aan de hand van inzichten in de complexiteit van kinderarbeid en in de perspectieven van werkende kinderen pogingen ondernomen om het onderwerp beter te kunnen omvatten. De aandacht van sociale wetenschappers voor kinderarbeid vanuit een perspectief dat afstand neemt van een eenzijdig beeld over werkende kinderen als onmondige slachtoffers roept ook nieuwe vragen op over de kennis van kinderarbeid uit het verleden. Hoe groot waren in West-Europa in de $19 \mathrm{e}$ eeuw de verschillen tussen de bedrijfstakken of regio's? In welke mate was de situatie van kinderen die werkten in de Waalse steenkoolnijverheid vergelijkbaar met die van werkende kinderen in de Gentse textielindustrie? En hoe was de situatie van werkende kinderen in de landbouw en in de thuisarbeid? Waren kinderen die niet werkten in alle gevallen beter af dan kinderen die wel werk hadden? Ook kunnen nieuwe vragen worden gesteld over de deelname van werkende kinderen aan de strijd voor de verbetering van de arbeidsomstandigheden van werknemers. Bestonden in de $19 \mathrm{e}$ eeuw organisaties van werkẹnde kinderen, zoals die vandaag op sommige plaatsen bestaan in Afrika, Latijns-Amerika en Azië? Namen aan het protest van de fabrieksarbeiders ook werkende kinderen deel? Hebben ook kinderen mee gestreden voor de invoering van een minimumleeftijd voor kinderarbeid? Nieuwe inzichten over kinderarbeid vandaag roepen met andere woorden ook een hele rij nieuwe vragen op over kinderarbeid in het verleden.

Voor dit themanummer werd gezocht naar auteurs die dit 'andere perspectief' op kinderarbeid kunnen illustreren, zowel vandaag als in het verleden. De bedoeling daarbij is niet om een nieuwe mythe in het leven te roepen; geen van de auteurs propageert een geromantiseerde visie die enkel gaat over hoe graag kinderen wel zouden werken of gewerkt hebben. De inzichten vanuit dit 'ander' perspectief willen niet in de plaats treden van de bestaande kennis over de harde levensomstandigheden van veel werkende kinderen vroeger of vandaag. Wel willen deze gegevens de bestaande kennis nuanceren, aanvullen en waar nodig corrigeren. De bijdrage van Ellen Schrumpf illustreert dit voortreffelijk. De auteur bekritiseert het dominante idee dat kinderen 'van nature' alleen maar zouden spelen en naar school gaan. Ze stelt dat arbeid voor kinderen op bepaalde plaatsen en op bepaalde momenten heel gewoon kan zijn, en niet per definitie een historische 'afwijking' is. Binnen bepaalde contexten kunnen werkende 
kinderen zelfs bevoorrecht zijn. Schrumpf geeft ook weer hoe haar eigen referentiekader wijzigde in de loop van haar onderzoek naar de situatie van werkende kinderen in twee Noorse fabrieken in de $19 \mathrm{e}$ eeuw. Ze vatte haar onderzoek aan vanuit een traditionele visie die kinderarbeid in het verleden vooral ziet als een economische noodzaak voor gezinnen en bedrijven. In de loop van het onderzoek breidde ze dit perspectief uit. Daarbij wou ze vooral op zoek naar waarom kinderen in de door haar bestudeerde bedrijven werkten, en waarom kinderarbeid aan het eind van de 19e eeuw zo drastisch daalde. Zo concentreerde ze zich meer en meer op werkende kinderen als actieve deelnemers aan de constructie van hun eigen leven en dat van hun gezinnen en niet louter als passieve subjecten van sociale structuren en processen. Ze stelt: "Change of perspective was necessary to get closer to the complexity of child labour in history".

\section{Wat is kinderarbeid?}

Over de afbakening van het begrip kinderarbeid rijzen heel wat vragen. Sommige auteurs, zoals William Myers ${ }^{(6)}$, stellen zelfs voor om de term 'kinderarbeid' te laten vallen, precies omdat er een allegaartje van situaties mee wordt aangeduid die nog moeilijk met elkaar in verband zijn te brengen. Myers wijst ook op het overmatig politieke gebruik van de term. In ieder geval werden reeds talrijke pogingen ondernomen om beter te omschrijven wat onder kinderarbeid moet worden verstaan. Er is echter weinig eensgezindheid en de discussie over de inhoud van het begrip kinderarbeid duurt dan ook voort.

\section{Een onderscheid tussen arbeid en werk}

In zijn bijdrage voor dit themanummer stelt Kristoffel Lieten dat er diverse vormen van 'kinderarbeid' zijn, die best niet door elkaar worden gehaald. De verschillende soorten werk die kinderen verrichten hebben niet allemaal schadelijke invloeden op kinderen, en moeten ook analytisch van elkaar worden onderscheiden. Ook andere auteurs maken hiervoor het onderscheid tussen de 'arbeid' van kinderen (child labour) en hun 'werk' (child work). Onder de term kinderarbeid worden de economische activiteiten van kinderen geplaatst die met exploitatie te maken hebben. Het gaat hier onder meer over fabrieksarbeid, kinderen die lange dagen werken in thuisateliers, het werk van zeer jonge kinderen, arbeid in slechte omstandigheden, arbeid die hinderlijk is voor de fysische, psychische en mentale ontwikkeling van kinderen en arbeid waardoor kinderen niet langer naar school kunnen gaan of kunnen spelen. Kinderarbeid krijgt een overwegend negatief label opgeplakt, en moet dan ook als zodanig worden afgeschaft. Daarnaast zijn kinderen echter ook economisch actief op een wijze die niet noodzakelijk schadelijk is voor hun ontwikkeling, waarvoor de term werk van kinderen wordt gebruikt. Hier gaat het onder meer over werk in degelijke omstandigheden in het kader van een opleiding, de verschillende taken van kinderen bij het huishou- 
den, kinderen die hun ouders helpen op het platteland of over activiteiten die kinderen niet de mogelijkheid ontnemen om onderwijs te volgen en die bevorderlijk zijn voor hun ontwikkeling. Van afschaffing is daarbij geen sprake.

Er is evenwel meer en meer discussie over de analytische kwaliteiten van het onderscheid tussen 'werk' en 'arbeid' om het fenomeen kinderarbeid beter te begrijpen. Het onderscheid wordt bijvoorbeeld enkel voor kinderen gemaakt. Voor het omschrijven van de economische activiteiten van volwassen arbeiders zijn 'werk' en 'arbeid' synoniemen. Er is ook een taalkundig probleem. In het Engels, en ook in het Nederlands of Spaans, is het inderdaad mogelijk om de woorden 'labour/arbeid', 'work/werk' of 'trabajo/labor' van elkaar te onderscheiden. In andere talen zijn echter geen onderscheiden woorden voorhanden. Zo worden in het Frans 'arbeid' en 'werk' telkens vertaald als 'travail'. Naast taalkundige bezwaren, zijn er echter ook inhoudelijke problemen met de voorgestelde tweedeling. Ben White stelt dat het niet mogelijk is om activiteiten van kinderen simpelweg op te delen in twee categorieën die ofwel 'goed' ofwel 'slecht' $z i j n n^{(7)}$. Hij stelt voor om de activiteiten van kinderen op één lijn te plaatsen, gaande van activiteiten die weinig controversieel zijn en zelfs goed voor hun ontwikkeling (bijvoorbeeld een krantenronde, lichte huishoudelijke taken, babysitten) tot de meest uitbuitende vormen van kinderarbeid (bijvoorbeeld slavenarbeid, arbeid in de chemische industrie, kinderprostitutie). Tussenin komen dan die activiteiten die in meerdere of mindere mate schadelijk dan wel bevorderlijk zijn voor kinderen. Dergelijk schema zou volgens White veel meer met de realiteit overeenstemmen.

In vele gevallen is het echter moeilijk om uit te maken of een bepaalde activiteit al dan niet schadelijk of bevorderlijk is voor de ontwikkeling van kinderen. Bepaalde activiteiten kunnen zowel schadelijk als bevorderlijk zijn. Het werk van kinderen in de landbouwsector bijvoorbeeld kan omwille van het gebruik van pesticiden of gevaarlijke machines zeer schadelijk zijn; tegelijkertijd kunnen kinderen echter ook leren hoe ze met bepaalde producten of machines moeten omgaan of biedt het werk hen ook de mogelijkheid om hun schoolgeld te betalen. Een aantal auteurs stelt dan ook voor om het onderscheid tussen 'werk' en 'arbeid', alsook tussen 'goede' en 'slechte' activiteiten, te laten vallen ${ }^{(8)}$. Het onderscheid tussen kinderarbeid en werk van kinderen schiet als analysekader tekort om het fenomeen kinderarbeid ook beter te begrijpen.

\section{Kinderarbeid: een typologie}

Naast het onderscheid tussen arbeid en werk, zijn er nog andere benaderingen om een beter inzicht te verwerven in het fenomeen kinderarbeid. Zo stelt Michel Bonnet vast dat kinderen in zeer diverse sectoren zijn tewerkgesteld ${ }^{(9)}$. Om beter de diversiteit van kinderarbeid te begrijpen, volgt Bonnet een typologie over kinderarbeid die reeds in 1982 door de Speciale Rapporteur van de Verenigde Naties, Boudhiba, werd uitgewerkt. Als criterium voor classificatie gebruikt deze typologie de door het werk tot stand gebrachte (min of meer flexibele) relatie tussen het kind en zijn gezin. Boudhiba 
onderscheidt elf verschillende vormen van kinderarbeid. Hij verdeelt deze elf verschillende vormen eerst in twee grote categorieën, namelijk werk uitgevoerd binnen of buiten het kader van het gezin. Verder maakt hij een onderscheid op basis van de wijze waarop de tewerkstelling is tot stand gekomen, namelijk al of niet met tussenkomst van een derde. In een afzonderlijke categorie bespreekt Boudhiba een aantal bijzondere vormen van kinderarbeid.

\section{Werk binnen het gezin}

a. Zonder tussenkomst van een derde

1. Familiale landbouw

2. Huisnijverheid

b. Met tussenkomst van een derde

3. Stukwerker

\section{Werk buiten het gezin}

a. Zonder tussenkomst van een derde

4. Kleine taken voor eigen rekening

b. Met tussenkomst van een derde

5. Kleine taken voor rekening van een derde

6. Seizoensarbeid in de landbouw

7. Leeropleiding

8. 'Sweatshop'

\section{Bijzondere gevallen}

9. 'Meiden voor alle werk' (huisbediendes)

10. Slavernij

11. Prostitutie

De bijzondere gevallen van kinderarbeid springen het meest in het oog en kregen ook internationaal de meeste aandacht. Onder meer documentairemakers hebben gewezen op kinderen die in erbarmelijke omstandigheden in zogenaamde 'sweatshops' werken, dit zijn ateliers of fabrieken waar ze vaak illegaal en zonder enige wettelijke bescherming lange werkdagen kloppen. Kinderen worden er ingeschakeld voor het maken van stukgoederen, vaak in onderaanneming van grote of zelfs multinationale ondernemingen. De arbeidsvoorwaarden worden eenzijdig opgelegd en het loon van de werkende kinderen ligt meestal nog lager dan dat van hun volwassen medearbeiders. Naar aanleiding van de totstandkoming van het IAO-Verdrag van 1999 over de ergste vormen van kinderarbeid ${ }^{(10)}$ kregen ook slavernij en gedwongen prostitutie van kinderen heel wat belangstelling.

De aandacht voor deze extreme vormen van exploitatie van kinderen mag echter de diversiteit van het fenomeen kinderarbeid niet uit het oog doen verliezen. In die zin is het voorgestelde schema in ieder geval bruikbaar om een beter inzicht te verwerven in de talrijke vormen van kinderarbeid. Ook helpt het schema eraan herinneren dat de overgrote meerderheid van de kinderen die werken vaak in weinig in het oog sprin- 
gende sectoren actief zijn, met name de landbouw en de populaire economie (of 'informele sector').

\section{Kinderen in paternalistische arbeidsrelaties}

Naast de diversiteit van kinderarbeid, zijn er ook gemeenschappelijke kenmerken. Een eerste voor de hand liggend kenmerk verwijst naar de persoon die de arbeid verricht. Onder kinderarbeid kunnen die economische activiteiten worden begrepen die door kinderen onder een bepaalde leeftijd (bijvoorbeeld veertien of vijftien jaar) worden uitgevoerd. Daarnaast worden werkrelaties van kinderen gekenmerkt door hun paternalistische karakter. Volgens Bernard Schlemmer is precies het paternalisme één van de basiskenmerken aan de hand waarvan kinderarbeid van volwassen arbeid kan worden onderscheiden ${ }^{(11)}$.

De situatie van kinderen die werken als 'meiden voor alle werk' (zie nummer 9 in de typologie van Boudhiba) is zeer illustratief voor een beter begrip van de draagwijdte van het paternalisme. In de groeiende metropolen in het Zuiden is het gebruik wijdverspreid om kinderen, voornamelijk meisjes, reeds op zeer jonge leeftijd te 'plaatsen' bij een ver familielid of een vage kennis in de stad. De kinderen, aan wie op die manier een zekere bescherming wordt geboden en zelfs een belofte op toekomstig werk, gaan er aan de slag als meiden voor alle werk. De arbeidsverhoudingen tussen de jonge huisbediendes en hun werkgevers hebben een aantal specifieke kenmerken. De kinderen worden op een informele wijze tewerkgesteld, via verwanten of vrienden van de ouders. De huisbediendes krijgen geen precies omschreven taak opgelegd, maar zijn ook letterlijk meiden 'voor alle werk': poetswerk, koken, de zorg voor kleine kinderen, onderhoud van de tuin, boodschappen doen,... Ze zijn er om te voldoen aan elke vraag, op haast dezelfde wijze als ook vele meisjes aan de huishoudelijke taken in hun eigen gezin meewerken. De kinderen hebben geen duidelijk vooraf vastgelegd werkschema of uurrooster. Huisbediendes dienen hast volledig ter beschikking te staan van hun werkgevers, dit op elk moment van de dag. In ruil voor hun beschikbaarheid en de taken die ze uitvoeren, kunnen ze - haast net zoals thuis - rekenen op de bescherming door hun werkgevers. De bescherming waar huisbediendes tijdens hun tewerkstelling op kunnen rekenen is echter zeer dubbelzinnig. Nu eens wordt de huisbediende beschouwd als de eigen zoon of dochter van het gezin; dan weer dient hij of zij louter als goedkope arbeidskracht. Precies deze dubbelzinnigheid wijst op het verfijnde en soms moeilijk zichtbare karakter van de exploitatie, die ook daarom paternalistisch is.

De karakteristieken van het werk van jonge huisbediendes gaan in meer of mindere mate ook op voor vele andere vormen van kinderarbeid. De relatie tussen een jongen van tien die in een garage gaat werken en zijn werkgever, kent bijvoorbeeld een zelfde dubbelzinnig karakter. In ruil voor een opleiding en de bescherming door de leer- 


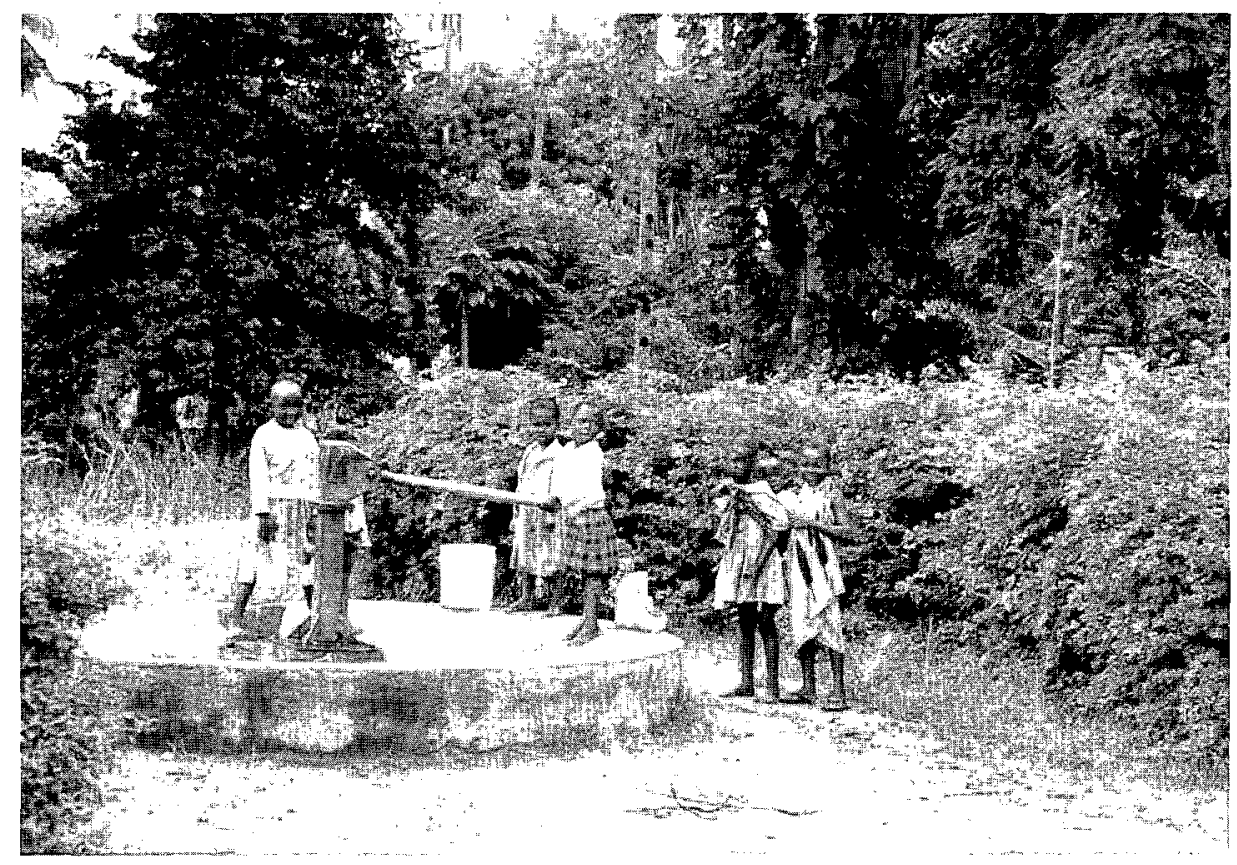

Waterdragers in Tanzania: hulp bij het huishouden of kinderarbeid? (collectie Kristoffel Lieten) 
meester krijgt het kind talrijke vooraf onbepaalde taken opgelegd. Nu eens beschouwt de werkgever hem daarbij als zijn eigen zoon, dan weer louter als goedkope arbeidskracht. Het paternalistische karakter van deze arbeidsrelatie kan telkens in twee richtingen worden begrepen. Enerzijds worden kinderen via hun (slecht of niet betaalde) arbeid uitgebuit; deze exploitatie verbergt zich echter achter een vorm van bescherming. Anderzijds krijgen kinderen via hun tewerkstelling een zekere vorm van bescherming; deze bescherming kan echter zeer snel omslaan in zeer concrete vormen van exploitatie. De paternalistische arbeidsverhouding dient dan, enerzijds, om overexploitatic van het werk van kinderen tegen te gaan, maar verbergt anderzijds ook de verfijning waarmee de arbeid van kinderen wordt uitgebuit.

\section{Hoeveel kinderen werken?}

\section{Over kinderarbeid in cijfers}

Talrijke rapporten over kinderarbeid geven reeds in de eerste of tweede paragraaf een schatting van het aantal kinderen dat wereldwijd aan het werk is. Meestal wordt dan verwezen naar de cijfers die het Internationaal Arbeidsbureau naar voor schuift. Volgens recente schattingen zouden wereldwijd minstens 120 miljoen kinderen tussen de 5 en 14 jaar werken. Als ook de deeltijds werkende kinderen worden meegeteld, zou dit cijfer oplopen tot 250 miljoen. De overgrote meerderheid daarvan is terug te vinden in de ontwikkelingslanden in Afrika, Azië en Latijns-Amerika ${ }^{(12)}$.

De juiste inschatting van het aantal werkende kinderen geeft echter aanleiding tot problemen ${ }^{(13)}$. In zijn bijdrage toont Lieten bijwoorbeeld aan hoe via 'de illusie van de precisie' uit de lucht gegrepen cijfers over kinderarbeid voor politieke en ideologische doelen worden aangewend. Hierboven haalden we reeds het vaak gebruikte onderscheid aan tussen arbeid en werk van kinderen en het probleem om een juiste afbakening te vinden van beide. Het is duidelijk dat de gebruikte definitie van 'kinderarbeid' ook invloed zal hebben op de cijfers. Een ander probleem volgt uit de sectoren waarin kinderen werkzaam zijn. De zogenaamde informele sector kreeg die naam mee, precies omdat het een sector is die buiten het formele circuit om functioneert: er is alvast geen enkele officiële registratie van het aantal werknemers dat in deze sector actief is. Over het aantal kinderen dat bijvoorbeeld als straatverkoper of autowasser aan de slag is kunnen we dan ook slechts zeer ruwe schattingen maken. Ook werken vele kinderen, onder meer omwille van een formeel verbod op kinderarbeid, in een of andere vorm van illegaliteit. Kenmerkend voor illegale activiteiten is dat geen precieze cijfers bestaan over het aantal betrokkenen, laat staan over hun leeftijd. Bovendien werken niet alle kinderen voltijds of het ganse jaar door: op het platteland werken bijvoorbeeld meer kinderen tijdens de oogstmaanden dan erbuiten. Het ogenblik van de telling kan de cijfers dan ook sterk vertekenen. 
Problemen bij de registratie van cijfers over kinderarbeid zijn niet het voorrecht van ontwikkelingslanden. Het is echter evenmin eenvoudig om betrouwbare cijfers te vinden over kinderarbeid in een moderne westerse staat met een degelijk uitgebouwde administratie en ambtenarenapparaat. Hoeveel werkende kinderen zijn er bijvoorbeeld in Belgie ${ }^{(14)}$ ? Kinderarbeid is in België gereglementeerd door de Arbeidswet van 16 maart 1971, zoals gewijzigd door de wet van 5 augustus 1992 betreffende de kinderarbeid $^{(15)}$ en het Koninklijk Besluit van 11 maart 1993 houdende uitvoeringsmaatregelen van deze wet ${ }^{(16)}$. De wet hanteert als principe het verbod van kinderarbeid: het is verboden voor kinderen jonger dan 15 jaar (of die nog onderworpen zijn aan de voltijdse leerplicht) arbeid te doen of te laten verrichten. Uitzonderingen op dit principieel verbod zijn mogelijk voor activiteiten die passen in de opvoeding of vorming van het kind en voor een limitatief aantal in de wet opgesomde activiteiten. Deze activiteiten betreffen onder meer de deelname van kinderen als acteur, figurant, zanger, muzikant of model aan filmopnamen, theater, televisieprogramma's, modeshows en fotosessies. Om een uitzondering te bekomen op het verbod van kinderarbeid moet diegene die kinderen voor één van deze activiteiten in dienst wil nemen telkens een individuele afwijking aanvragen bij de Inspectie van de sociale wetten van het Federaal Ministerie van Tewerkstelling en Arbeid. In 1997 werden 357 individuele aanvragen ingediend, waarvan in totaal 349 aanvragen werden toegestaan. Om echter voor 1997 het aantal werkende kinderen te kennen, dient ook te worden nagegaan hoeveel inbreuken op het verbod op kinderarbeid werden vastgesteld. In 1997 voerde de Inspectie van de sociale wetten in het kader van de wet op de kinderarbeid 46 opdrachten uit, die leidden tot 77 vaststellingen. Uit de door de administratie opgemaakte statistieken kan echter niet worden afgeleid hoeveel kinderen bij deze vaststellingen betrokken waren. Het is dan ook niet mogelijk om voor België op basis van officieel gepubliceerde cijfers het aantal kinderen onder de 15 jaar dat werkt op te geven. We weten enkel dat voor 349 kinderen een individuele afwijking op het verbod op kinderarbeid werd toegestaan, en dat de arbeidsinspectie 77 vaststellingen over het verbod op kinderarbeid heeft verricht waarbij een onbekend aantal kinderen was betrokken.

Uit studies over andere Europese landen weten we dat ook in het Westen heel wat kinderen werken voor geld. In zijn bijdrage verwijst Ben White naar onderzoek in Nederland waaruit blijkt dat midden de jaren ' 80 drie vierden van alle kinderen tussen 13 en 17 jaar geregeld in deeltijdse jobs waren tewerkgesteld. De meerderheid van de kinderen werken 'illegaal': de aard, de duur of het tijdstip van de activiteiten zijn volgens de Nederlandse wet verboden. In Groot-Brittannië is het bijvoorbeeld heel gebruikelijk dat jongens vanaf hun 12 of 13 jaar's morgens een krantenronde doen of dat meisjes werken als babysitter of in de horeca ${ }^{(17)}$. Uit recent onderzoek blijkt dat een groot aantal schoolgaande Britse jongeren ervaring heeft met één of andere vorm van betaalde arbeid. Eén derde tot de helft van de Britse kinderen onder de 16 jaar heeft reeds gewerkt. In België is geen gelijkaardig onderzoek voorhanden naar het voorko- 
men van betaalde (deeltijdse) arbeid van kinderen jonger dan 15 of 16 jaar. Nochtans zijn er ook voor ons land aanwijzingen dat kinderen werken voor geld, zoals babysitten, klussen in de tuin of meewerken met thuisarbeid van ouders (bv. kinderen die meewerken met hun ouders die thuis stukwerk verrichten). Misschien zullen in België een minder groot aantal kinderen betaalde arbeid verrichten in vergelijking met Nederland of Groot-Brittannië, maar anderzijds kan worden aangenomen dat ook in ons land (deeltijdse) kinderarbeid geen marginaal fenomeen is. De officieel geregistreerde cijfers zeggen dan uiteindelijk heel weinig over de omvang van het fenomeen kinderarbeid in België. Waarom zouden officiële cijfers uit andere landen zoveel betrouwbaarder zijn? En wat is in dit licht de kwaliteit van cijfers over kinderarbeid in het verleden?

\section{Alle kinderen werken}

Een kritische bespreking van de schattingen (of zijn het gissingen?) van het aantal werkende kinderen in de wereld leert alvast een aantal belangrijke zaken. Een eerste vaststelling is dat we niet weten hoeveel kinderen precies aan het werk zijn. Anderzijds weten we wel dat het er een groot aantal zijn en dat velen met specifieke vormen van uitbuiting te maken krijgen. Belangrijk is echter dat de moeilijkheden bij het tellen van werkende kinderen opnieuw verwijzen naar de weinig relevante kennis die we hebben over wat kinderarbeid precies inhoudt. $\mathrm{Nu}$ worden al te vaak hele ruwe schattingen gegeven, waarbij de verschillen tussen de activiteiten die kinderen verrichten zelden mee in rekening worden gebracht.

Cijfers over kinderarbeid zijn dan ook niet neutraal. In de media worden ze steevast gepresenteerd in combinatie met beelden en verhalen over de meest schrijnende vormen van exploitatie. Allicht kan er op die manier bij het brede publiek enig medeleven worden opgewekt voor het lot van werkende kinderen. Anderzijds geeft het op die manier verspreide verhaal over kinderarbeid een wel zeer vertekend beeld van de werkelijkheid. De combinatie van cijfers en beelden stelt het voor alsof alle kinderen die werken dat in situaties van extreme exploitatie doen. Lieten stelt in zijn bijdrage over India dat door het verschijnsel kinderarbeid tot massale proporties op te blazen en daarbij de meest schrijnende vormen als voorbeeld te nemen, publiekelijk steun kan worden gevonden voor initiatieven om in het Noorden handelsbeperkende maatregelen in te voeren en zo de eigen arbeidsmarkten af te schermen. Daarbij wordt weinig of geen rekening gehouden met de concrete realiteit zoals werkende kinderen die beleven. Kinderen uit het Zuiden moeten zich inderdaad hard inspannen om in moeilijke omstandigheden voldoende middelen van bestaan te verwerven. Tezelfdertijd biedt hun werk hun echter ook een zekere fierheid en is het een middel om een iets minder onzeker bestaan op te bouwen. Sommige werkende kinderen vinden dan ook dat het wijdverspreide beeld over kinderarbeid hun situatie soms nog bemoeilijkt. Ze stellen dat ze veel meer nood hebben aan respect voor wat ze doen dan aan medelijden met hun lot. 
Sociologen vragen zich af of ons idee over kinderarbeid niet nog verder moet worden bijgesteld. Schlemmer wijst erop dat wanneer een meer correcte interpretatie van kinderarbeid wordt gegeven, een andere soort werkelijkheid naar voor komt ${ }^{(18)}$. De auteur vraagt zich af of het niet juister zou zijn om te stellen dat alle kinderen werken, maar niet in dezelfde omstandigheden. Zowel in het Noorden als in het Zuiden dragen kinderen, ook tijdens hun socialisatie, immers actief bij tot de welvaart van hun land. Kinderen werken in de fabriek, op het land, thuis, op straat, maar ook op school. Telkens verrichten ze activiteiten die maatschappelijk nuttig zijn. Kinderen die bijvoorbeeld in de landbouw werken dragen onmiddellijk bij tot de economische productie en de rijkdom van hun land. Maar ook kinderen die naar school gaan, leveren een belangrijke bijdrage aan de economie. In zijn artikel voor dit nummer werkt Jens Qvortrup het idee uit dat kinderen altijd hebben gewerkt, maar dat de wijze waarop ze zijn tewerkgesteld afhankelijk is van het economische systeem waarin ze leven. De vorm die de verplichte activiteiten van kinderen vandaag in de geïndustrialiseerde wereld heeft aangenomen is 'schoolwerk'. Leerlingen, scholieren en studenten investeren immers een aanzienlijk deel van hun tijd en van hun capaciteiten in de productie en reproductie van kennis. Door hun schoolwerk vandaag verzekeren ze dat de samenleving ook in de toekomst eenzelfde of zelfs hoger welvaartsniveau zal kunnen aanhouden. Waar kinderen vroeger als arbeidskrachten werden ingezet in de landbouw, nijverheid en industrie, kregen ze met de modernisering een nieuwe rol te vervullen. Door ook het werk van kinderen op school in de discussie in te brengen, opent Qvortrup een reeks nieuwe perspectieven en vragen over kinderarbeid, die ook voor de studie van kinderarbeid in het verleden van belang zijn. Zo moet volgens deze analyse kinderarbeid worden bestudeerd binnen de economische productiewijze en organisatie van de samenleving waarin het fenomeen plaatsvond. De stelling dat alle kinderen betrokken zijn bij maatschappelijk nuttige, en zelfs noodzakelijke activiteiten, verlegt ook het zwaartepunt van de discussie. Het probleem is dan uiteindelijk niet zozeer om een antwoord te vinden op de vraag of kinderen al of niet werken (of: hoeveel kinderen al of niet werken) maar wel waar en in welke omstandigheden kinderen werken.

\section{Arbeid en onderwijs}

Het debat over kinderarbeid verwijst vaak naar het belang van onderwijs voor kinderen. Arbeid en onderwijs worden voorgesteld als alternatieven of zelfs als tegenpolen: kinderen die werken kunnen niet naar school gaan en omgekeerd. Het ontbreken van een adequaat onderwijssysteem zou ook een (gedeeltelijke) verklaring geven voor het feit dat zoveel kinderen werken. Hieruit echter afleiden dat kinderarbeid automatisch zal verminderen door het louter voorzien in meer scholen is echter een al te eenvoudig idee. Olga Nieuwenhuys beschrijft in haar artikel hoe werkende kinderen in Kerala, 
India, tussen 1930 en 1980 massaal deelnamen aan de strijd voor de erkenning van hun recht op onderwijs. De uiteindelijke veralgemening van het onderwijs in Kerala leverde voor werkende kinderen wat hun emancipatic betreft duidelijk een aantal voordelen op, maar had ook belangrijke schaduwzijden. Zo werd de druk op plattelandskinderen om te voldoen aan de vereisten van de school voortaan opgeteld bij hun dagelijkse arbeidsverplichtingen. De toename van onderwijs ging niet gepaard met een herstructurering van de economie of arbeidsmarkt, waardoor veel kinderen in Kerala nog steeds bleven (en blijven) werken.

Belangrijk voor de analyse van de relatie tussen arbeid en onderwijs is ook de inhoud van het onderwijs dat op school wordt gegeven. Is de kennis die scholen bieden ook relevant voor kinderen uit arme gezinnen? In hoeverre sluit het aangeboden onderwijs aan bij de noden en verwachtingen van kinderen? Daarnaast kunnen ook de omstandigheden waarin het onderwijs wordt verstrekt de antrekkelijkheid of zelfs relevantie van de school meebepalen. Hoeveel leerlingen zijn er in de klas, op welke wijze worden straffen uitgedeeld? Veel kinderen werken precies om naar school te kunnen gaan. Meisjes werken bijvoorbeeld vaak om de kosten te betalen die aan het onderwijs verbonden zijn, zowel voor zichzelf als voor hun broers of familieleden die onder hetzelfde dak wonen. Verder is ook de houding van de ouders ten aanzien van het onderwijs van hun kinderen van belang. Niet alle ouders zien er het nut van in hun kinderen naar school te sturen. Ze vragen zich af wat het nut is van een diploma te behalen wanneer ze weten dat hun kinderen toch geen reële arbeidskansen hebben. Ouders verwijzen ook naar de dringende noodzaak om over een voldoende gezinsinkomen te beschikken. Het loon dat kinderen verdienen door te gaan werken, hoe karig ook, is voor veel gezinnen noodzakelijk om te kunnen overleven.

De auteurs van het rapport Working children: reconsidering the debates stellen dat het voor elk land een doel op zichzelf moet zijn om een adequaat onderwijssysteem uit te bouwen ${ }^{(19)}$. Wanneer het onderwijs er wil in slagen te verhinderen dat kinderen zouden werken, dan moeten zowel ouders als kinderen overtuigd zijn van de waarde van het onderwijs, en van de relevantie ervan voor hun (later) leven. In die zin kunnen landen in het Zuiden allicht ook lessen trekken uit de ervaring van economisch meer ontwikkelde landen, zoals Groot-Brittannië of de Verenigde Staten. Niettegenstaande beide landen over een in vergelijking beter ontwikkeld onderwijssysteem beschikken met kosteloos onderwijs voor iedereen, bestaat ook in die landen voor kinderen een reële spanning tussen arbeid en onderwijs. Het zou, aldus het rapport, een vergissing zijn voor economisch zwakkere landen aan te nemen dat een beter onderwijs ook onvermijdelijk zal leiden tot een oplossing van alle problemen die met kinderarbeid verbonden zijn.

Het is dan allicht ook juister om te stellen dat schoolse activiteiten kinderen niet uitsluiten uit de wereld van arbeid. Omgekeerd kan arbeid het kinderen wel onmoge- 


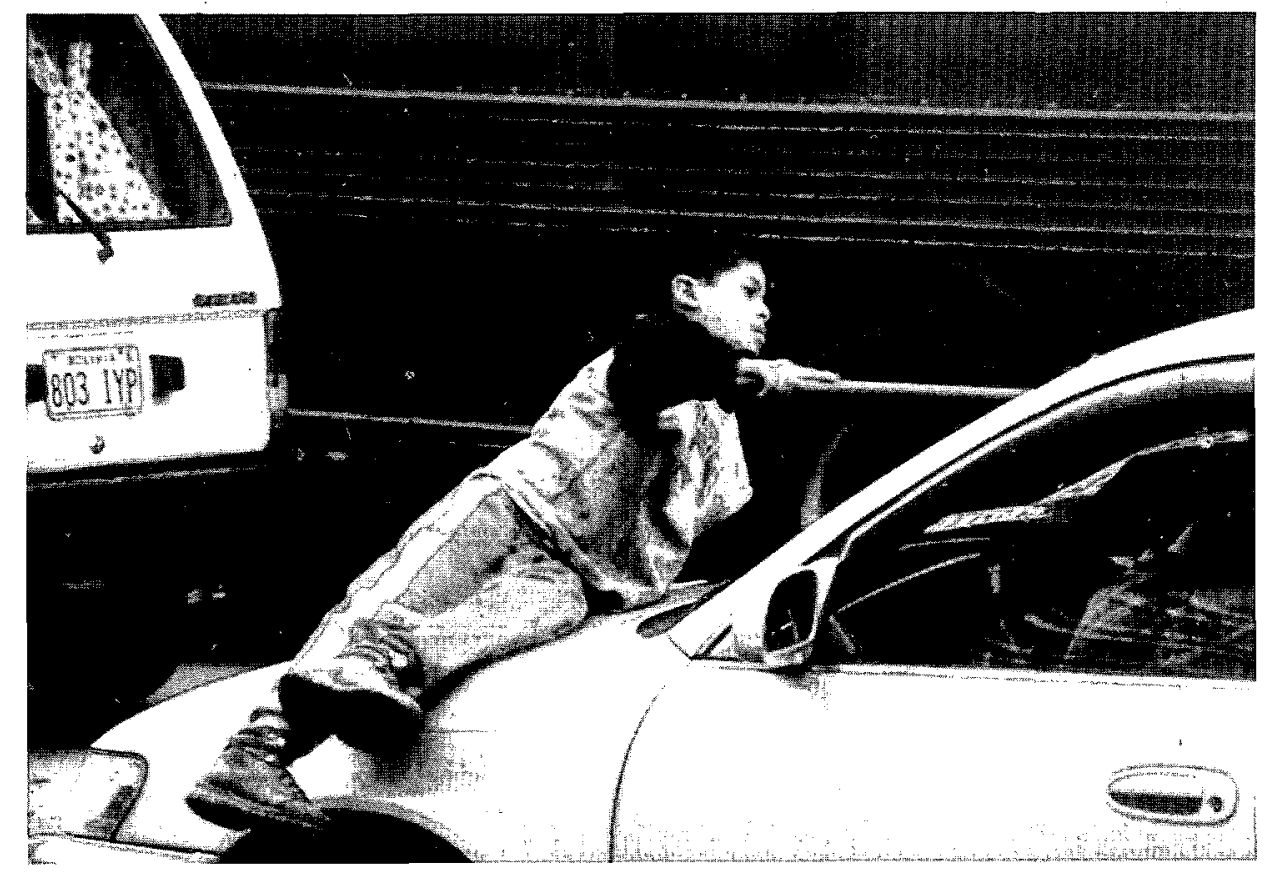

Over het aantal kinderen dat als straatverkoper of autowasser aan de slag is kunnen we slechts ruwe schattingen maken. Foto: ruitenwasser in La Paz, Bolivia (collectie Kristoffel Lieten) 
lijk maken om naar school te gaan ${ }^{(20)}$. Uiteindelijk moeten beide, arbeid en onderwijs, dan zowel op zichzelf als in verhouding tot elkaar worden beschouwd. Centraal daarbij is dat alle kinderen, ook werkende kinderen, recht hebben op gratis en kwalitatief onderwijs.

\section{Zelforganisaties van werkende kinderen}

In talrijke stedelijke kernen op verschillende continenten bestaan organisaties van werkende kinderen die opkomen voor betere arbeidsomstandigheden. De organisaties worden in de literatuur aangeduid met het acroniem NAT's, wat staat voor het Spaanse 'Niños, niñas y adolescentes trabajadores'. Sommige NAT's sluiten zich bij het formuleren van hun eisen voor een betere bescherming aan bij de bredere arbeidersbeweging. Zo was één van de eerste acties van ENDA, cen West-Afrikaanse organisatie van werkende kinderen, de deelname aan de 1-meioptocht in een aantal WestAfrikaanse steden. Tijdens de actie werden namens de werkende kinderen van Dakar en andere steden concrete eisen opgesteld voor de verbetering van hun arbeidsomstandigheden ${ }^{(2)}$. Zo pleitten huisbediendes voor ondertekende en geregistreerde arbeidscontracten, of eisten kinderen die als zelfstandige werken (zoals kruiers, schoenpoetsers, autowachters, kleine handelaars) om de prijzen voor het leveren van diensten en goederen aan te passen aan een recente devaluatie. Het beeld dat uit deze eisen naar voor komt heeft nog weinig te maken met het klassieke portret van werkende kinderen als 'sukkelaartjes'. Naast ENDA, zijn ook op andere plaatsen in het Zuiden dergelijke organisaties actief. In Azië is er onder meer 'Bhima Sangha' en 'Bal Mazdoor' (beide in India), in Latijns-Amerka zijn bijvoorbeeld 'Manthoc' (Peru) en de beweging van straatkinderen 'MNMNR' (Brazilië) actief ${ }^{222}$. Rechtstreeks bij deze organisaties betrokken personen schreven voor dit themanummer een afzonderlijke bijdrage.

Organisatieśs van werkende kinderen stellen nadrukkelijk de vraag om hun situatie als geheel te bekijken. Ook vinden ze dat het weinig zin heeft om interventiestrategieën over kinderarbeid te baseren op enkel één aspect van hun bestaan, met name het feit dat ze werken, zonder de bredere sociale context in rekening te brengen. Naast aandacht voor hun arbeidsomstandigheden, vragen ze dan ook om rekening te houden met hun recht op gezondheidszorg of hun recht op degelijk onderwijs.

In hun standpunten wijken de zelforganisaties van werkende kinderen af van de meer traditionele schema's, zoals de tegenstelling arbeid en onderwijs. De NAT's vragen bijvoorbeeld om het onderwijs aan hun situatie aan te passen. Ze willen gerespecteerd worden als werknemers, én tezelfdertijd ook rechten zoals het recht op onderwijs, op gezondheidszorg en op ontspanning erkend zien. Daarnaast komen ze eveneens op voor deelname aan de politieke besluitvorming op lokaal, nationaal en internationaal niveau. Naar aanleiding van de Verklaring van Kundapur van $1996^{(23)}$, en verwijzend 
naar de toen geplande conferenties van de Internationale Arbeidsorganisatie (IAO) ter voorbereiding van een nieuw verdrag over de ergste vormen van kinderarbeid, stelden ze bijvoorbeeld dat werkende kinderen een evenredige stem moeten hebben: "Indien tijdens deze conferenties 20 ministers aanwezig zinn, willen we dat ook 20 werkende kinderen aanwezig $z i j n "$.

Tijdens conferenties in Amsterdam en Oslo, die werden georganiseerd ter voorbereiding van het IAO-Verdrag over de ergste vormen van kinderarbeid, was telkens een delegatie van organisaties van werkende kinderen aanwezig. Tijdens de Internationale Arbeidsconferentie in juni 1998 was dat echter niet het geval: de organisaties van werkende kinderen worden niet gerekend tot de traditionele werknemersorganisaties die in de IAO zijn vertegenwoordigd. Indien de werkende kinderen binnen de bestaande structuren hun stem willen laten horen, zouden ze zich aldus eerst tot de werknemersorganisaties van hun land moeten richten om via die weg ook tijdens de Internationale Arbeidsconferenties van de IAO gehoord te kunnen worden. Het is echter maar de vraag in hoeverre de traditionele arbeidersbewegingen momenteel bereid zijn om ook de belangen van werkende kinderen in hun eisenbundels op te nemen. Hun officiële standpunt, de afschaffing van kinderarbeid, is voor vele vakbonden een onoverkomelijke hinderpaal om werkende kinderen als volwaardige leden, als werknemers, te aanvaarden. Daarnaast krijgen de organisaties van werkende kinderen ook de vraag opgeworpen wie ze nu eigenlijk vertegenwoordigen. Hun democratische legitimiteit wordt met andere woorden in vraag gesteld. Organisaties van werkende kinderen, zoals trouwens ook sommige vakbonden voor volwassen werknemers, staan in die zin voor de voortdurende uitdaging om te verantwoorden wie ze zijn, wie ze vertegenwoordigen en op welke wijze hun standpunten tot stand komen.

\section{Reacties op kinderarbeid}

Doorheen de reacties op het fenomeen kinderarbeid zijn verschillende posities te onderscheiden ${ }^{(24)}$. Een eerste positie pleit voor de afschaffing van kinderarbeid: tot een bepaalde leeftijd moet een verbod op kinderarbeid worden ingevoerd en afgedwongen. Een tweede positie legt de nadruk op de regulering van kinderarbeid: onder meer arbeidsbeschermende maatregelen moeten de uitbuiting van werkende kinderen tijdens hun arbeid tegengaan. Een derde positie wil de inspanningen ondersteunen van werkende kinderen die opkomen voor een verbetering van hun situatie. Hier ligt de nadruk op 'empowerment' van werkende kinderen. Tenslotte is er ook een (feitelijke) 'laisser faire'-houding: kinderarbeid is nu eenmaal een werkelijkheid waar op korte termijn niets aan te doen is. Er wordt verwacht dat de economische ontwikkeling vanzelf wel zal zorgen voor het terugdringen van kinderarbeid, waarbij de markt zelf zijn regulerend werk zal doen. 


\section{'Laisser faire'}

Stephen Cunningham bespreekt in zijn bijdrage de houding van Britse hoge ambtenaren tegenover de regulering van voor- en naschoolse arbeid van kinderen. Uit zijn analyse van de positie die hoge ambtenaren bij het 'Home Office' tussen 1929 en 1932 innamen blijkt hoe zij zich voornamelijk op basis van een 'laisser faire'-ideologie verzetten tegen een verstrenging van de bestaande wetgeving. Hun protest en invloed reikten volgens Cunningham zo ver dat ze de positie van Groot-Brittannië bij de onderhandelingen over het IAO-Verdrag van 30 april 1932 over een minimumleeftijd in niet-industriële tewerkstelling beïnvloedden. Volgens de 'orthodoxe visie' van de ambtenaren zou de tewerkstelling van kinderen tijdens de schoolvakanties en voor of na de schooltijd voornamelijk een positieve invloed hebben voor hun ontwikkeling, en zelfs bijdragen tot het verminderen van de jeugddelinquentie. Belangrijk was vooral het verzet van de hoge ambtenaren tegen overheidsoptreden op de arbeidsmarkt: door het aanwenden van kinderen als (goedkope) arbeidskrachten via overheidsregulering te bemoeilijken, zouden economische problemen ontstaan voor de vele kleine Britse ondernemingen die kinderen tewerkstelden.

\section{Afschaffen van kinderarbeid}

Onder meer als antwoord op een 'laisser faire'-houding ijvert de IAO voor de afschaffing van kinderarbeid. De LAO werd na de Eerste Wereldoorlog opgericht om naast andere doelstellingen ook de negatieve effecten van internationale economische concurrentie op de arbeidsomstandigheden tegen te gaan, en te verhinderen dat landen via ondermaatse arbeidswetgeving oneerlijke voordelen zouden halen uit de internationale handel. In zijn overzicht van kinderarbeid in het internationale recht vroeger en nu wijst Arne Vandaele erop dat de IAO, zeker sinds het Verdrag betreffende de minimumleeftijd voor toelating tot het arbeidsproces van 1973, de algehele afschaffing van kinderarbeid wil bewerkstelligen. Waar in vroegere IAO-verdragen een zekere soepelheid bestond, gaat de organisatie vandaag uit van een principieel verbod op kinderarbeid voor kinderen die onder een bepaalde minimumleeftijd vallen. Ook andere internationale verdragen hebben als doel de algehele afschaffing van kinderarbeid onder een bepaalde leeftijd (in principe vijftien jaar). De vraag naar de toelaatbaarheid van kinderarbeid wordt hierdoor gereduceerd tot een mathematisch onderzoek naar de leeftijd van kinderen: wanneer een kind een bepaalde leeftijd nog niet heeft bereikt, is het verbod op kinderarbeid van kracht.

Recent nam de IAO een nieuw verdrag aan over de uitroeiing van de ergste vormen van kinderarbeid. Dit verdrag beschouwt als ergste vormen van kinderarbeid alle vormen van slavernij, kinderprostitutie, het inzetten van kinderen voor illegale activiteiten (in het bijzonder de productie van en handel in drugs), en alle werk dat door zijn aard of de omstandigheden waarin het wordt uitgevoerd schadelijk is voor de gezondheid, veilig- 


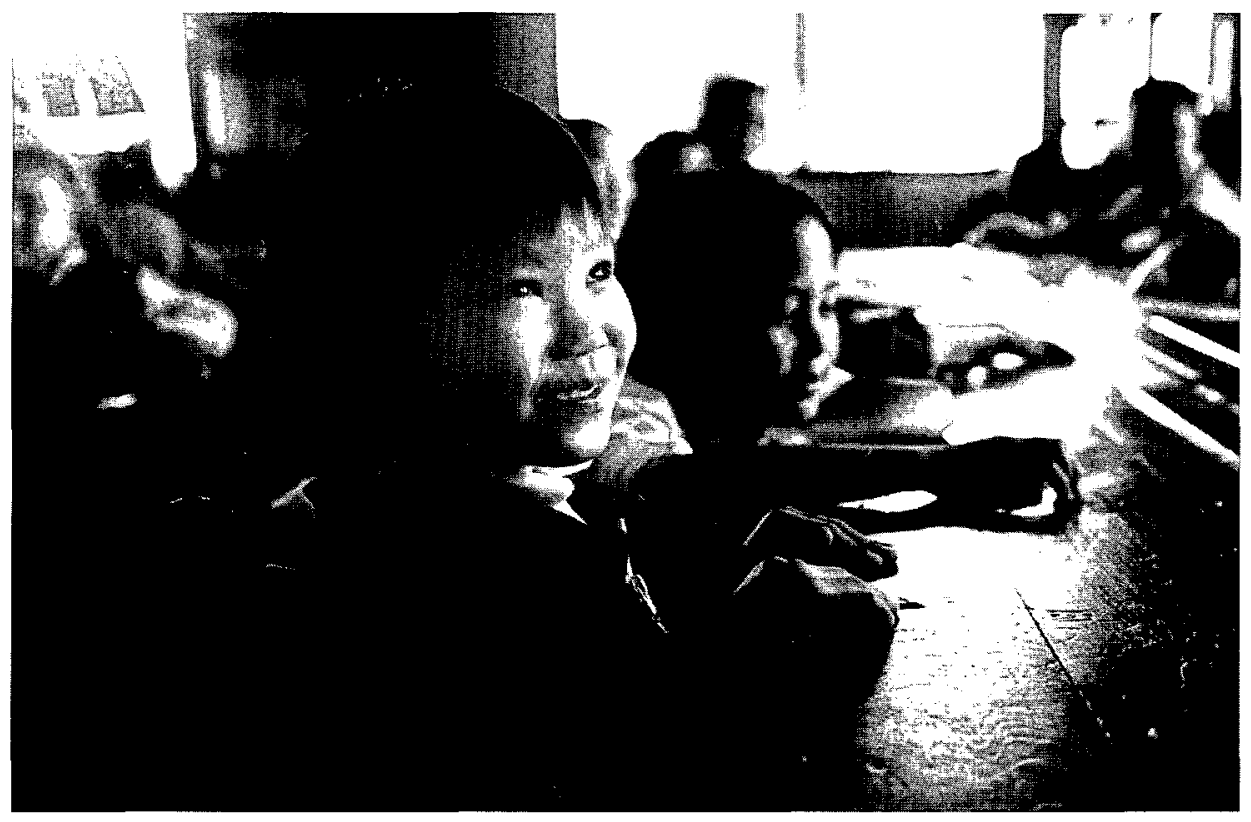

Fundamenteel is dat alle kinderen, ook werkende kinderen, recht hebben op gratis onderwijs (foto Sonny Plasschaert) 
heid of zedelijkheid van kinderen. Verschillende auteurs, onder wie White, zien dit verdrag als een realistische poging van de IAO om kinderarbeid aan te pakken. Gezien de enorme omvang van het fenomeen kinderarbeid, is het onmogelijk om op korte termijn de doelstelling om alle kinderarbeid af te schaffen ook daadwerkelijk te realiseren. Daarom wil de IAO prioritair de meest schrijnende vormen van uitbuiting van kinderen aanpakken, met name via de onmiddellijke afschaffing van de ergste vormen van kinderarbeid. Zoals ook Vandaele opmerkt betekent dit echter niet dat de IAO haar abolitionistische houding heeft laten vallen: het volledig uitroeien van kinderarbeid blijft voor de IAO nog steeds als ultieme doelstelling gehandhaaf.

\section{Reguleren van kinderarbeid}

Naast de onmiddellijke afschaffing van de ergste vormen van kinderarbeid en de afschaffing op lange termijn van alle kinderarbeid, ijvert de IAO via het IPEC-program$\mathrm{ma}^{(25)}$ ook voor het verbeteren op korte termijn van de arbeidsomstandigheden van werkende kinderen. De positie 'reguleren' wil uitbuiting van werkende kinderen tegengaan via het wettelijk regelen en afdwingbaar maken van arbeidsbeschermende maatregelen. Het samengaan van de posities 'afschaffen' en 'reguleren' van kinderarbeid is echter geen eenvoudige zaak. De finale doelstelling 'afschaffen van kinderarbeid' verhindert vaak de installatie van wetgeving die de verbetering van de arbeidsomstandigheden van kinderen op het oog heeft.

In zijn bijdrage merkt Cunningham op dat organisaties die in Groot-Brittannië opkomen voor hervorming van de wetgeving op de kinderarbeid niet per definitie tegen kinderarbeid gekant zijn. De meeste erkennen dat goed georganiseerde vormen van kinderarbeid - dit is wanneer hun arbeid degelijk is gereguleerd (door de overheid) en gecontroleerd (door vakbonden, scholen en ouders) - ook positieve effecten kan hebben. Pleiten voor meer regulering betekent dan ook niet automatisch ijveren voor de afschaffing van kinderarbeid. Integendeel, juist de regulering en het afdwingen van de regels kan de uitbuiting van kinderarbeid tegengaan.

\section{'Empowerment' van werkende kinderen}

Ten slotte is er ook de positie die werkende kinderen wil ondersteunen in hun inspanningen om hun werk- en lẹefomstandigheden te verbeteren. Zelforganisaties van werkende kinderen verdedigen zelf een regulerende houding tegenover kinderarbeid. Een empowerment-perspectief ijvert voor het creëren van meer mogelijkheden voor organisaties van werkende kinderen om aan het debat over kinderarbeid te participeren. De posities reguleren en empowerment zijn posities die dan ook vaak samengaan en elkaar versterken: zelforganisaties van werkende kinderen vragen steun voor hun eisen voor meer en betere arbeidsbescherming. Tezelfdertijd kunnen arbeidsbeschermende maatregelen (bijvoorbeeld de wettelijke erkenning van het recht op vereniging) ook de 


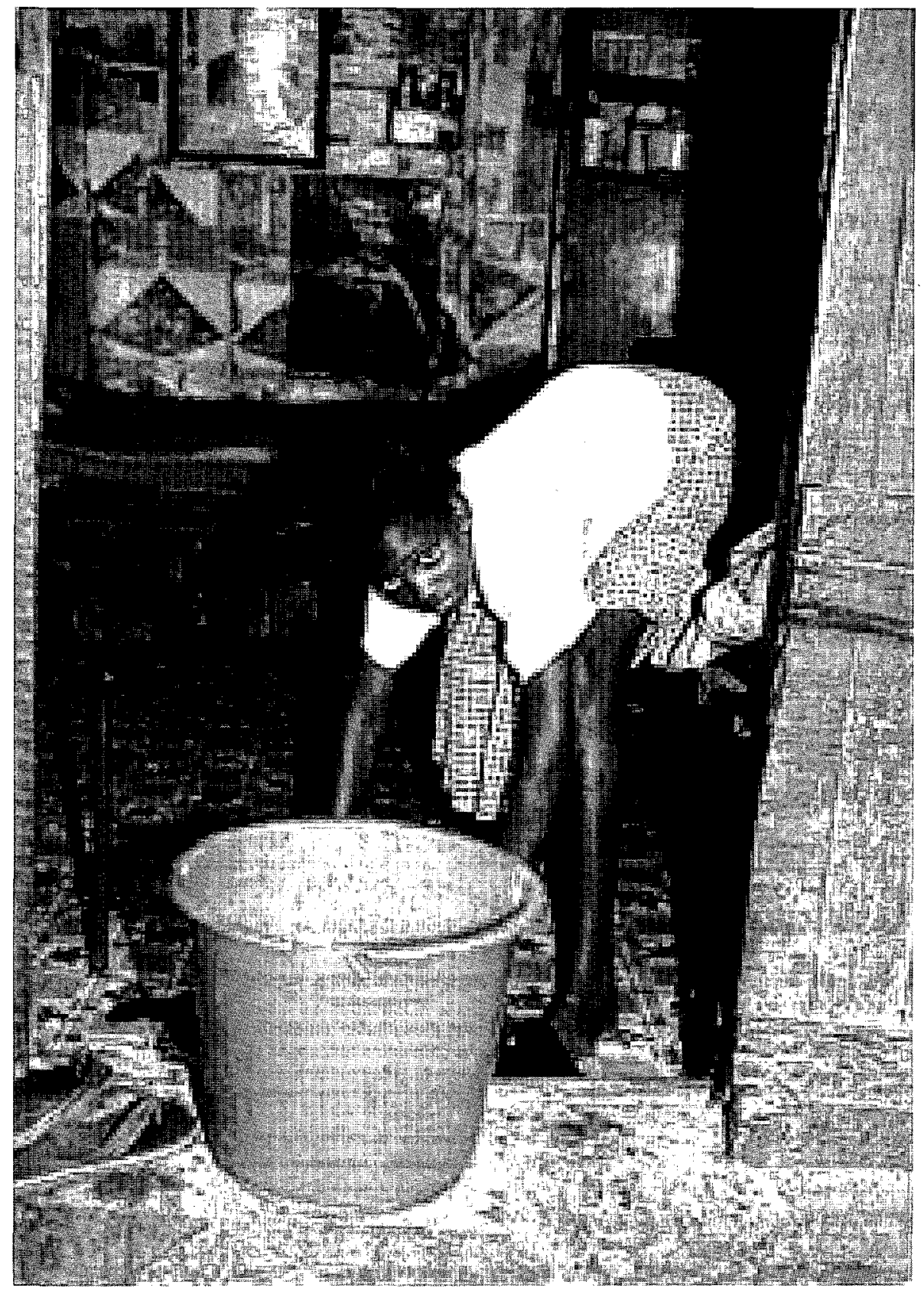

De ergste vormen van uitbuiting gebeuren in de informele sector. Foto: jonge huisbediende in de buitenwijken van Dakar, Senegal (foto J. Maillard, 1996, wwwilo.org) 
zelforganisaties van werkende kinderen ondersteunen ${ }^{(26)}$. Zelforganisaties van werkende kinderen benadrukken het belang van participatierechten en pleiten voor de erkenning van hun recht op arbeid in waardigheid. Volgens de NAT's is het recht op arbeid een fundamenteel mensenrecht, dat ook voor kinderen moet worden gewaarborgd. Ze zijn het dan ook niet eens met de roep om afschaffing van kinderarbeid. Kinderen die werken om het inkomen van hun familie te helpen verzekeren, of nog om hun schoolgeld te betalen, hebben volgens de NAT's recht op respect voor hun werk, en moeten op de eerste plaats voldoende bescherming kunnen krijgen bij de uitoefening van hun arbeid $^{(27)}$.

Vanzelfsprekend zijn de NAT's geen voorstanders van extreme uitbuiting op het werk, en kanten ze zich tegen slavernij of gedwongen prostitutie. Ze zijn echter zeer kritisch over het recente IAO-Verdrag over de ergste vormen van kinderarbeid. Ze klagen vooral het automatisme aan waarmee dit verdrag slavernij of prostitutie met arbeid van kinderen verwart. De in het verdrag opgenomen ergste vormen van kinderarbeid zijn volgens hen op de eerste plaats misdrijven, die ook als zodanig moeten worden bestreden. Door ook deze misdrijven kinderarbeid te noemen, drukt het verdrag zich weinig respectvol uit over het werk van de overgrote meerderheid van werkende kinderen.

In zijn artikel benoemt Vandaele de positie die toestanden van armoede en extreme exploitatie van het werk van kinderen bevestigt als een vorm van 'extreem realisme': de wereld is zoals hij is, en daar is niet veel aan te doen. De eisen van organisaties van werkende kinderen, met name respect voor hun recht op arbeid in waardigheid, hebben echter niks met dergelijke 'laisser faire'-houding te maken. Integendeel, werkende kinderen willen hun situatie verbeteren door meer overheidsregulering. Hun standpunten staan lijnrecht tegenover de orthodoxe neoliberale visie zoals die bijvoorbeeld door hoge Britse ambtenaren werd verdedigd.

\section{Besluit}

Kinderen leveren een vaak over het hoofd geziene waardevolle bijdrage aan de samenleving, zowel door hun deelname aan het arbeidsproces als via hun schoolwerk. Dat kinderen via hun werk ook een plaats in de wereld opeisen, betekent echter niet dat werkende kinderen geen moeilijkheden hebben. De NAT's vragen dan ook niet om hen te idealiseren. Wel vragen ze op de eerste plaats aandacht voor hun perspectief op de wereld. Ze wijzen erop dat werkende kinderen worden uitgebuit en hun job in vaak zeer ondankbare omstandigheden moeten uitvoeren. Maar ze zeggen ook dat veel kinderen fier zijn over hun werk, en dat ze het geld dat ze verdienen goed kunnen gebruiken. Ze eisen dat beleidsmakers meer naar hen zouden luisteren bij het nemen van maatregelen over kinderarbeid. 
Dit themanummer illustreert dat het mogelijk is om bij de geschiedschrijving over kinderarbeid met dit 'ander perspectief' rekening te houden. Zo wijst Schrumpf erop dat kinderen die in de 19e eeuw in Noorwegen in de industrie werkten zowel inzake loon als arbeidsduur beter af waren in vergelijking met kinderen die op dat moment in Noorwegen in de landbouw of als huisbediendes werkten. Werkende kinderen waren volgens haar bevoorrechte kinderen. Deze inzichten roepen vragen op over een aantal als vanzelfsprekend ervaren etappes in de evolutie van het nationale en internationale recht over kinderarbeid. White wijst erop dat huisbediendes door de Nederlandse Arbeidswet van 1919 werden uitgesloten van de algemene arbeidsduurbeperking tot 8 uur per dag en 45 uur per week. Nochtans gingen in die periode vele meisjes reeds voor hun 12 jaar als huisbediende werken, vaak langer dan 14 uur per dag. Vandaele stelt immers vast dat in de eerste verdragen van de IAO een minimumleeftijd voor kinderarbeid werd ingevoerd precies in de sector waar kinderen het best af waren, met name de industrie. Het werk van kinderen in de landbouwsector en als huisbediendes werd door het internationaal recht veel minder geproblematiseerd. Nochtans vonden precies daar de ergste vormen van uitbuiting plaats: de minst bevoorrechte kinderen kregen zowel nationaal als internationaal de minste aandacht. Ook vandaag gaat de meeste aandacht naar kinderarbeid in formele arbeidssectoren. Het is nochtans in die sectoren dat een zekere vorm van bescherming en controle bestaat. Kinderen uit deze sectoren verwijderen, betekent in de praktijk vaak niet méér dan hen wegduwen naar jobs met veel slechtere arbeidsomstandigheden en een nog lager loon. Ook de benadering die prioritair de ergste vormen van kinderarbeid wil aanpakken, ziet kinderen die in de landbouw, als huisbediende of in de informele sector werken over het hoofd. Nochtans zijn daar de meeste kinderen aan de slag, en vinden ook daar de meest subtiele vormen van uitbuiting en onderdrukking van werkende kinderen plaats. Niet de bestrijding van slavernij, dwangarbeid of kinderprostitutie is het probleem - integendeel, nog veel meer middelen moeten worden ingezet - maar wel de verwarring tussen deze vormen van brute onderdrukking en kinderarbeid.

De afwezigheid van het perspectief van werkende kinderen vertekent de kennis over kinderarbeid, zowel over vroeger als over vandaag. Niet alle maatregelen die werden/ worden genomen blijken immers ook effectief de werk- en leefomstandigheden van kinderen te verbeteren. Het belang om de sociale rust te behouden, of om de eigen concurrentiepositie van een land te vrijwaren, bleek soms veel meer van tel te zijn dan de reële verbetering van het lot van werkende kinderen. In een aantal gevallen droeg de roep voor afschaffing van kinderarbeid zelfs bij tot het verslechteren van de situatie van werkende kinderen. Het verbod op kinderarbeid makt het voor kinderen immers moeilijker om zich op regelgeving te beroepen die zou kunnen bijdragen om hun situatie te verbeteren, zoals het recht om bij een vakbond aan te sluiten of op arbeidsbeschermende maatregelen. Ook bij de studie van kinderarbeid moeten globale analyses voortdurend worden geconfronteerd met sterk gediversifieerde lokale contexten. 
Onder bepaalde voorwaarden en in bepaalde omstandigheden kan arbeid ook voor kinderen emanciperend werken; in andere omstandigheden is hun arbeid niet veel meer dan een afstompende bezigheid. In veel gevallen is kinderarbeid in meer of mindere mate zowel het ene als het andere. Een meer genuanceerde kijk op kinderarbeid in het verleden, waarbij zowel met de diversiteit van kinderarbeid als met het perspectief van werkende kinderen wordt rekening gehouden, kan dan ook bijdragen tot het vergroten van het inzicht in discussies over kinderarbeid vandaag.

\section{Bijlage}

\section{Verklaring van Kundapur (1996)}

Verklaring opgesteld door 34 vertegenwoordigers uit 33 landen in Afrika, Latijns-Amerika en Azië die deelnamen aan de eerste internationale bijeenkomst van werkende kinderen in Kundapur (India), van 24 november tot 8 december $1996^{(28)}$.

\section{The Kundapur Declaration, November-December 1996}

"We, the working children of the Third World, propose

1. We want recognition of our problems, our initiatives, proposals and our process of organisation;

2. We are against the boycott of products made by children;

3. We want respect and security for ourselves and the work that we do;

4. We want an education system whose methodology and content are adapted to our reality;

5. We want professional training adapted to our reality and capabilities;

6. We want access to good health care for working children;

7. We want to be consulted in all decisions concerning us, at local, national or international level;

8. We want the root causes of our situation, primarily poverty, to be addressed and tackled;

9. We want more activity in rural areas so that children do not have to migrate to the cities. We are against exploitation at work, but we are in favour of work with dignity and appropriate hours, so that we have time for education and leisure.

With regard to the conferences which will be taking place, we want representation on an equal basis (if there are 20 ministers present, we want 20 working children to also be present). We will have discussions with our ministers but we do not want them to represent us." 
(1) Deze tekst kwam tot stand in het kader van het programma IUAP (nr. P4/27), gefinancierd door de Belgische Staat. Diensten van de Eerste Minister - Federale diensten voor wetenschappelijke, technische en culturele aangelegenheden.

(2) R. DE HERDT, B. DE GRAEVE, Kinderarbeid 1800-1914, Gent: Museum voor Industriële Archeologie en Textiel, 1981, p. 4.

(3) R. DE HERDT, B. DE GRAEVE. Kinderarbeid 1800-1914 [...1, p. 29.

(4) B. DE WILDE, Kinderen en arbeid: onverzoenbaar of toch niet? In: Samenleving en Politiek, 6(1999)9.

(5) P. DE WITTE, Alles is omgekeerd. Hoe de werklieden vroeger leefden. 1848-1918, Leuven, 1986, p. 68. In: B. DE WILDE, Kinderen en arbeid: $/ . .$. .

(6) W.E. MYERS, Considering Child Labour. Changing terms, issues and actors at the international level. In: Childhood, 6(1999)1, p. 22.

(7) I. MCKECHNIE, S. HOBBS (eds.). Working children: Reconsidering the debates. Report of the International Working Group on Child Labour, Amsterdam: DCI/ISPAN, 1998 pp. 37-40.

(8) Zie bv, verscheidene auteurs in B. SCHLEMMER (ed.). L'enfant exploité - oppression, mise au travail, prolétarisation. Paris: Karthala, 1996, 522 p. Gepubliceerd in het Engels als: B. SCHLEMMER (ed.). The exploited child, London: Zed Books. 2000.

(9) M. BONNET, Regards sur les enfants travailleurs. La mise au travail dans le monde contemporain: analyse et études de cas, Lausanne: Page deux, 1998. pp. 43-61.

(10) Zie de bijdrage van A. Vandaele in dit nummer, Kinderarbeid in het internationale recht vroeger en $n u$.

(1I) In: B. SCHLEMMER, L'enfant exploité l.../, pp. 7-27.

(12) BIT, Le travail des enfants. L'intolérable en point de mire, Genève, 1996, p. 3.

(13) B. SCHLEMMER. L'enfant exploité 1..... pp. 7-27.

(14) De cijfers zijn gebaseerd op het jaarverslag 1997 van de bevoegde federale administratie: Administratie van de inspectie van de sociale wetten, Activiteitsverslag 1997. Brussel: Federaal Ministerie van Tewerkstelling en Arbeid.

(15) Belgisch Staatsblad, 28.08.1992.

(16) Belgisch Staatsblad. 09.04.1993.

(17) B. PETTITT (ed.), Children and work in the UK: Reassessing the issues, Londen: Child Poverty Action Group. 1998.

(18) B. SCHLEMMER, L'enfant exploité [..., pp. 7-27.

(19) 1. McKECHNIE, S. HOBBS (eds.), Working Children [...l, pp. 37-40.

(20) B. SCHLEMMER, L'enfant exploité [...j. pp. 7-27.

(21) ENDA TM leunesse Action. Working children and youths of West Afrika get organised, Dakar: EDNA TiersMonde leunesse Action, 1997, pp. 3-9.

(22) Voor een bespreking van een aantal zelforganisaties van werkende kinderen, zie A. SWIFT, Working Children Get Organised. An introduction to working children's organisations, London: International Save the Children Alliance, 1999, p. 40.

(23) Zie de tekst opgenomen in bijlage.

(24) B. WHITE. Children, Work and 'Child Labour: Changing Responses to the Employment of Children. Den Haag: Institute of Social Studies, 1994, pp. 7-8.

(25) 'International Programme on the Elimination of Child Labour' van de IAO, zie Internet, http://www.ilo.org.

(26) B. WHITE, Children, Work [...J. pp. 7-8.

(27) Over de discussies over kinderarbeid en het perspectief van werkende kinderen: Niños, Niñas y Adolescentes Trabajadores (NAT's). Zelforganisaties van werkende kinderen en het debat over kinderarbeid. In: Mores: pedagogisch tijdschrift voor morele problemen, 42(1998)214. pp. 319-337; K. HANSON. A. VANDAELE, Working Children and International Labour Law: A Critical Analysis. In: Infomation Bulletin $N^{\circ} 4$ for the International Conference 'Rethinkig Childhood', Bondy (France), 15-17.11.2000, pp.31-5I.

(28) Bron: International Working Group on Child Labour, Have we asked the children? Discussion paper, BangaloreAmsterdam: Concerned for Working Children/DCI-NL, 1997, p. 17. 


\section{Bibllografie}

- M. BONNET, Regards sur les enfants travailleurs. La mise au travail dans le monde contemporain: analyse et ćtudes de cas, Lausanne: Page deux, 1998, 231 p.

- A. CUSSIANOVICH VILLARAN, Some premises for reflection and social practices with working children and adolescents, San Isidro: Rädda Barnen, 1997, 26 p.

- B. DE WILDE, Kinderen en arbeid: onverzoenbaar of toch niet? In: Samenleving en Politiek, 6(1999)9.

- B. DE WILDE. The voice of working children in Belgium (1800-1914), In: Information Bulletin $\mathrm{N}^{\circ} 4$ for the International Conference 'Rethinking Childhood', Bondy (France). 15-17.11.2000. pp. 12-19.

- ENDA TM leunesse Action, Working children and youths of West Africa get organised, Dakar: ENDA TiersMonde leunesse Action, 1997, 52 p.

- K. HANSON, Niños, Niñas y Adolescentes Trabajadores (NAT's). Zelforganisaties van werkende kinderen en het debat over kinderarbeid. In: Mores: pedagogisch tijdschrift voor morele problemen, 42(1998)214, pp. 319-337.

- K. HANSON. A. VANDAELE, Working Children and International Labour Law: A Critical Analysis. In: Information Bulletin $N^{\circ} 4$ for the International Conference 'Rethinking Childhood', Bondy (France). 15-17.11.2000. pp. 3151.

- A. JAMES, C. IENKS, A. PROUT, Theorizing Childhood, Cambridge: Polity, 1998, 247 p.

-1. MCKECHNIE, S. HOBBS (eds.). Working Children: Reconsidering the debates. Report of the International Working Group on Child Labour, Amsterdam: DCI/ISPCAN, 1998, pp. 37-40.

- P. MILJETEIG, Children's democratic rights: Are we ready? What can we learn from young workers. In: A.B. SMITH. M. GALLOP. K. MARSHALL. K. NAIRN (eds.). Advocating for Children. International Perspectives on Children's Rights. Dunedin: University of Otago Press, 2000. pp. 159-175.

- W.E. MYERS, Considering Child Labour. Changing terms, issues and actors at the international level. In: Childhood, 6(1999)1, pp. 13-26.

- O. NIEUWENHUYS, The paradox of child labor and anthropology. In: Annual Review of Anthropology. ( 1996$) 25$, pp. 237-251.

- B. SCHLEMMER (ed.), Lenfant exploité - oppression. mise au travail. prolétarisation. Paris: Karthala, 1996. 522 p.; Gepubliceerd in het Engels als: B. SCHLEMMER (ed.). The exploited child, London: Zed Books, 2000. $338 \mathrm{p}$.

- A. SWIFT, Working Children Get Organised. An introduction to working children's organisations, London: International Save the Children Alliance, 1999. 40 p.

- B. WHITE, Children, Work and 'Child Labour': Changing Responses to the Employment of Children, Den Haag: Institute of Social Studies. 1994. 62 p.

- M. WOODHEAD. Children's perspectives on their working lives. A participatory study in Bangladesh. Ethiopia. The Philippines, Guatemala, El Salvador and Nicaragua, Stockholm: Rädda Barnen, 1998, 153 p. 